\title{
Deep levels generated by thermal oxidation in p-type $4 \mathrm{H}-\mathrm{SiC}$
}

$\operatorname{AUTHOR}(S)$ :

Kawahara, Koutarou; Suda, Jun; Kimoto, Tsunenobu

\section{CITATION:}

Kawahara, Koutarou ...[et al]. Deep levels generated by thermal oxidation in p-type 4H-SiC. Journal of Applied Physics 2013, 113(3): 033705.

\section{ISSUE DATE:}

2013-01-17

URL:

http://hdl.handle.net/2433/187956

\section{RIGHT:}

(C) 2013 American Institute of Physics. This article may be downloaded for personal use only. Any other use requires prior permission of the author and the American Institute of Physics. 


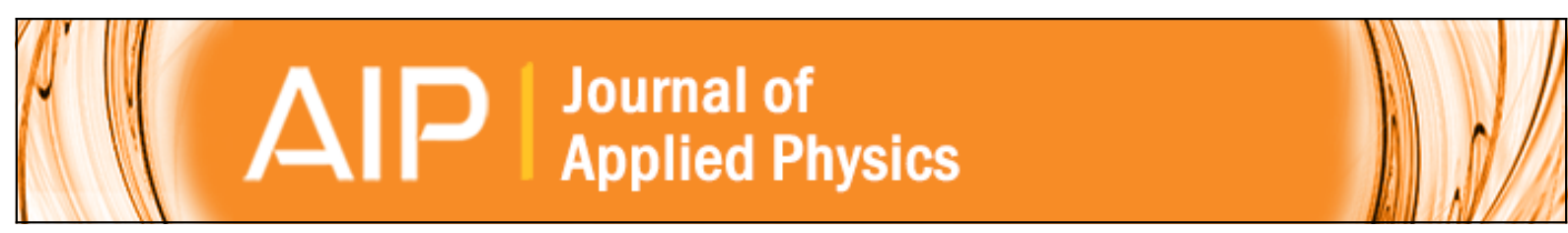

\section{Deep levels generated by thermal oxidation in p-type $4 \mathrm{H}-\mathrm{SiC}$}

Koutarou Kawahara, Jun Suda, and Tsunenobu Kimoto

Citation: Journal of Applied Physics 113, 033705 (2013); doi: 10.1063/1.4776240

View online: http://dx.doi.org/10.1063/1.4776240

View Table of Contents: http://scitation.aip.org/content/aip/journal/jap/113/3?ver=pdfcov

Published by the AIP Publishing

\section{Articles you may be interested in}

Anharmonic vibrations of the dicarbon antisite defect in $4 \mathrm{H}-\mathrm{SiC}$

Appl. Phys. Lett. 100, 132107 (2012); 10.1063/1.3699269

Analytical model for reduction of deep levels in SiC by thermal oxidation

J. Appl. Phys. 111, 053710 (2012); 10.1063/1.3692766

Major deep levels with the same microstructures observed in n-type 4H-SiC and $6 \mathrm{H}-\mathrm{SiC}$

J. Appl. Phys. 109, 013705 (2011); 10.1063/1.3528124

Reduction of deep levels generated by ion implantation into $\mathrm{n}$ - and p-type $4 \mathrm{H}-\mathrm{SiC}$

J. Appl. Phys. 108, 033706 (2010); 10.1063/1.3456159

Deep levels induced by reactive ion etching in $\mathrm{n}$ - and $\mathrm{p}$-type $4 \mathrm{H}-\mathrm{SiC}$

J. Appl. Phys. 108, 023706 (2010); 10.1063/1.3460636

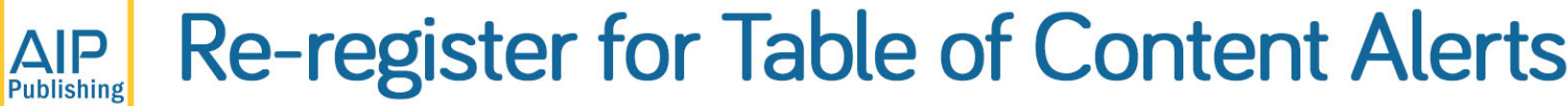




\title{
Deep levels generated by thermal oxidation in p-type 4H-SiC
}

\author{
Koutarou Kawahara, ${ }^{\text {a) }}$ Jun Suda, and Tsunenobu Kimoto ${ }^{\text {b) }}$ \\ Department of Electronic Science and Engineering, Kyoto University, Katsura, Nishikyo, Kyoto 615-8510, \\ Japan
}

(Received 15 November 2012; accepted 28 December 2012; published online 17 January 2013)

\begin{abstract}
Thermal oxidation is an effective method to reduce deep levels, especially the $\mathrm{Z}_{1 / 2}$-center $\left(E_{\mathrm{C}}-0.67 \mathrm{eV}\right)$, which strongly suppresses carrier lifetimes in n-type $4 \mathrm{H}-\mathrm{SiC}$ epilayers. The oxidation, however, simultaneously generates other deep levels, HK0 $\left(E_{\mathrm{V}}+0.79 \mathrm{eV}\right)$ and $\mathrm{HK} 2\left(E_{\mathrm{V}}+0.98 \mathrm{eV}\right)$ centers, within the lower half of the bandgap of $\mathrm{SiC}$, where the HK0 center is a dominant deep level with a concentration of about $1 \times 10^{13} \mathrm{~cm}^{-3}$ after oxidation. By comparing deep levels observed in three sets of p-type $4 \mathrm{H}-\mathrm{SiC}$ : oxidized, electron-irradiated, and $\mathrm{C}^{+}$- or $\mathrm{Si}^{+}$-implanted samples, we find that the HKO and HK2 centers are complexes including carbon interstitials such as the di-carbon interstitial or di-carbon antisite. Other defects observed in p-type 4H-SiC after electron irradiation or after $\mathrm{C}^{+} / \mathrm{Si}^{+}$implantation are also studied. (C) 2013 American Institute of Physics.

[http://dx.doi.org/10.1063/1.4776240]
\end{abstract}

\section{INTRODUCTION}

In producing high-power, high-temperature, and highfrequency devices, $\mathrm{SiC}$ is one of the most fascinating semiconductors. Deep levels in the SiC epilayers, however, prevent the development of high-performance $\mathrm{SiC}$ bipolar devices. The deep levels work as recombination centers resulting in the reduction of carrier lifetimes ${ }^{1}$ and also work as carrier traps, leading to the reduction in conductivity. Therefore, deep levels, especially the $\mathrm{Z}_{1 / 2}$ center, ${ }^{2}$ a "lifetime killer" in n-type $4 \mathrm{H}-\mathrm{SiC},{ }^{3,4}$ must be controlled.

In recent years, two effective methods were found to reduce the $Z_{1 / 2}$ center: (i) $\mathrm{C}^{+}$implantation followed by $\mathrm{Ar}$ annealing $^{5,6}$ and (ii) thermal oxidation. ${ }^{7}$ In both, excess carbon atoms induced by $\mathrm{C}^{+}$implantation/oxidation diffuse into the deeper region of a $\mathrm{SiC}$ epilayer during postimplantation annealing/oxidation and fill carbon vacancies $\left(\mathrm{V}_{\mathrm{C}}\right){ }^{6-8}$ The $\mathrm{Z}_{1 / 2}$ center most likely contains $\mathrm{V}_{\mathrm{C}}{ }^{9-12}$ and based on photo-EPR and electrical characterization ${ }^{13,14}$ the origin has recently been identified as the acceptor levels of $\mathrm{V}_{\mathrm{C}}$. The $\mathrm{Z}_{1 / 2}$ concentration is thus strongly reduced by these processes $\left(\mathrm{C}^{+}\right.$implantation and thermal oxidation), leading to very long carrier lifetimes $(20-30 \mu \mathrm{s})$ in n-type SiC. ${ }^{15,16}$

In contrast, new deep levels, HK0 $\left(E_{\mathrm{V}}+0.79 \mathrm{eV}\right)$ and HK2 $\left(E_{\mathrm{V}}+0.98 \mathrm{eV}\right)$ centers, are observed after thermal oxidation or $\mathrm{C}^{+}$implantation, which are probably related to the interstitials diffusing from the $\mathrm{SiO}_{2} / \mathrm{SiC}$ interface (oxidation) or from the implanted region $\left(\mathrm{C}^{+}\right.$implantation $){ }^{7,8}$ Although effects of $\mathrm{HK} 0$ and $\mathrm{HK} 2$ centers on carrier lifetimes are negligible compared with the $\mathrm{Z}_{1 / 2}$ center, ${ }^{8}$ these can affect lifetimes when the $Z_{1 / 2}$ centers are eliminated. In addition, investigation of the generated defects, the HK0 and HK2 centers, should lead us to a comprehensive understanding of

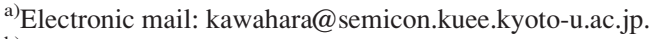

${ }^{b}$ Also at Photonics and Electronics Science and Engineering Center (PESEC), Kyoto University, Katsura, Nishikyo, Kyoto 615-8510, Japan.
}

the $\mathrm{Z}_{1 / 2}$ reduction mechanism by thermal oxidation or $\mathrm{C}^{+}$ implantation, which is required for full control of carrier lifetimes in SiC epilayers.

In this study, we compare depth profiles and thermal stability of the HKO and HK2 centers in three sets of p-type 4H-SiC: (i) oxidized, (ii) electron-irradiated, and (iii) $\mathrm{C}^{+}-$or $\mathrm{Si}^{+}$-implanted samples, and discuss the origins of these traps.

\section{EXPERIMENTS}

The starting materials were Al-doped p-type 4H-SiC (0001) epilayers $(12 \mu \mathrm{m}$ thickness with acceptor concentration $\left(N_{\mathrm{a}}\right)$ of $7 \times 10^{15} \mathrm{~cm}^{-3}$, or $120 \mu \mathrm{m}$ thickness with $N_{\mathrm{a}}$ of $\left.7 \times 10^{14} \mathrm{~cm}^{-3}\right)$. (i) The first set of samples was oxidized at different temperatures $\left(1150,1200,1300\right.$, and $\left.1400^{\circ} \mathrm{C}\right)$ for various periods $(1.3-16.5 \mathrm{~h})$ in $100 \%$ oxygen ambient, whereas (ii) the second set of samples was irradiated with $150 \mathrm{keV}$ electrons (fluence: $1.0 \times 10^{17} \mathrm{~cm}^{-2}$ ). (iii) The third set of samples was implanted with $10-50 \mathrm{keV}$ carbon (or $25-110 \mathrm{keV}$ silicon) ions with a total dose of $1 \times 10^{13} \mathrm{~cm}^{-2}$ or $1 \times 10^{14} \mathrm{~cm}^{-2}$ (implanted atom concentration: $1 \times 10^{18} \mathrm{~cm}^{-3}$ or $1 \times 10^{19} \mathrm{~cm}^{-3}$ ), forming a 140-nm-box-profile. The $\mathrm{C}^{+}$-implanted (or $\mathrm{Si}^{+}$-implanted) samples were annealed in Ar ambient at various temperatures (1000, 1300, 1440, 1500, 1700 , and $1800^{\circ} \mathrm{C}$ ) for $20 \mathrm{~min}$. For deep level transient spectroscopy (DLTS) measurements, $\mathrm{Ti}$ was employed as Schottky contacts (typical diameter: $1 \mathrm{~mm}$ ). The backside ohmic contacts were made of a Ti/Al/Ni $(20 \mathrm{~nm} / 100 \mathrm{~nm} /$ $80 \mathrm{~nm}$ ) layer annealed at $1000^{\circ} \mathrm{C}$ for $2 \mathrm{~min}$. A period width of $0.205 \mathrm{~s}$ was employed in all DLTS measurements performed in this study. The depth profiles of trap concentrations up to $10 \mu \mathrm{m}$ were measured by changing the reverse bias voltage up to $100 \mathrm{~V}$ in the DLTS measurements. To monitor deeper regions (over $10 \mu \mathrm{m}$ ), the samples were mechanically polished from the surfaces, and the DLTS measurements were repeated. Additional deep levels, though, did not appear by polishing. 


\section{RESULTS AND DISCUSSION}

\section{A. Deep levels after thermal oxidation}

Figure 1 shows the DLTS spectra obtained from a depth of $\sim 4 \mu \mathrm{m}$ for an as-grown sample before and after thermal oxidation at $1300{ }^{\circ} \mathrm{C}$ for $15.9 \mathrm{~h}$. In the as-grown sample, GP1 $\left(E_{\mathrm{V}}+0.46 \mathrm{eV}\right)$ and $\mathrm{D}\left(E_{\mathrm{V}}+0.63 \mathrm{eV}\right)$ centers were observed. The GP1 center is located at a deeper level than the boron acceptor (shallow boron level, $E_{\mathrm{V}}+(0.26-0.39) \mathrm{eV}$ (Refs. 17 and 18)). In contrast, the D center is a well-known deep level in p-type $4 \mathrm{H}-\mathrm{SiC}\left(E_{\mathrm{V}}+(0.54-0.73) \mathrm{eV}\right),{ }^{17-20}$ which has been attributed to a boron atom in a silicon site with an adjacent carbon vacancy $\left(\mathrm{B}_{\mathrm{Si}}-\mathrm{V}_{\mathrm{C}}\right){ }^{18,21,22}$ After oxidation, the D center disappeared, whereas the HK0 $\left(E_{\mathrm{V}}+0.79 \mathrm{eV}\right)$ and HK2 $\left(E_{\mathrm{V}}+0.98 \mathrm{eV}\right)$ centers appeared. The HK0 and HK2 centers are both observed in RIE-etched samples ${ }^{20,23}$ and electron-irradiated samples ${ }^{20}$ after Ar annealing (950$1000{ }^{\circ} \mathrm{C}$ ), whereas the HK2 center is detected occasionally in as-grown samples. ${ }^{20}$ Because these two centers are observed after thermal oxidation, the two deep levels may be related to the $\mathrm{C}$ (or $\mathrm{Si}$ ) interstitials diffusing from the $\mathrm{SiO}_{2} / \mathrm{SiC}$ interface during the oxidation.

\section{Comparison between experimental defect profiles and calculated interstitial profiles after thermal oxidation}

Figure 2 shows depth profiles of the HK0 center after oxidation at various temperatures for $1.3 \mathrm{~h}$. When oxidation is conducted at higher temperatures, the defect concentration is higher and the HKO center is distributed to a deeper region, which is consistent with an expected distribution of interstitials after diffusion from the $\mathrm{SiO}_{2} / \mathrm{SiC}$ interface. In Ref. 8, we introduced a calculation model for $\mathrm{C}_{\mathrm{I}}$ diffusion and recombination with $\mathrm{V}_{\mathrm{C}}$ during thermal oxidation, and showed that depth profiles of the $\mathrm{Z}_{1 / 2}$ center after oxidation can be predicted using the model. In this study, however, it is very difficult to propose an accurate diffusion model for calculation of the HK0 distributions because (i) $V_{C}$ concentration (and the distribution) in p-type $\mathrm{SiC}$ is not known, and (ii) as discussed in the Sec. III A 2 the HK0 center may originate from a $\mathrm{C}$-interstitial complex rather than a single interstitial. Thus, for the calculation of the HK0 distributions, we

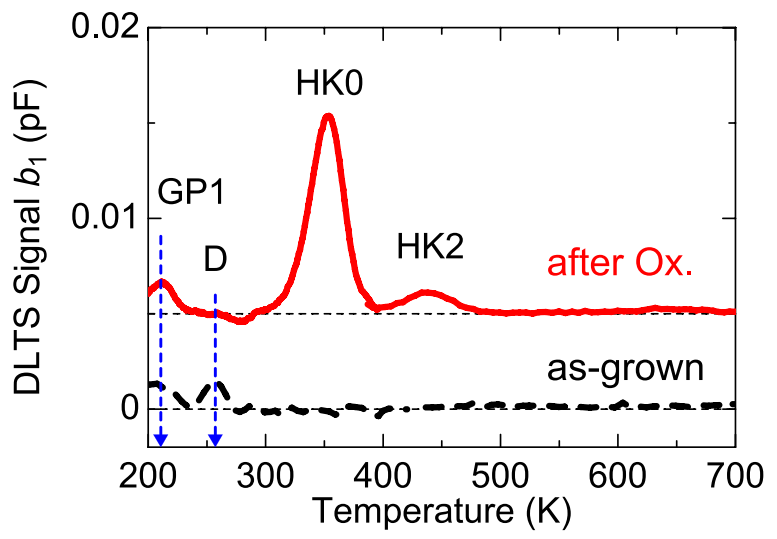

FIG. 1. DLTS spectra for the as-grown p-type $4 \mathrm{H}-\mathrm{SiC}$ (dashed line) before and after thermal oxidation at $1300{ }^{\circ} \mathrm{C}$ for $15.9 \mathrm{~h}$ (solid line).

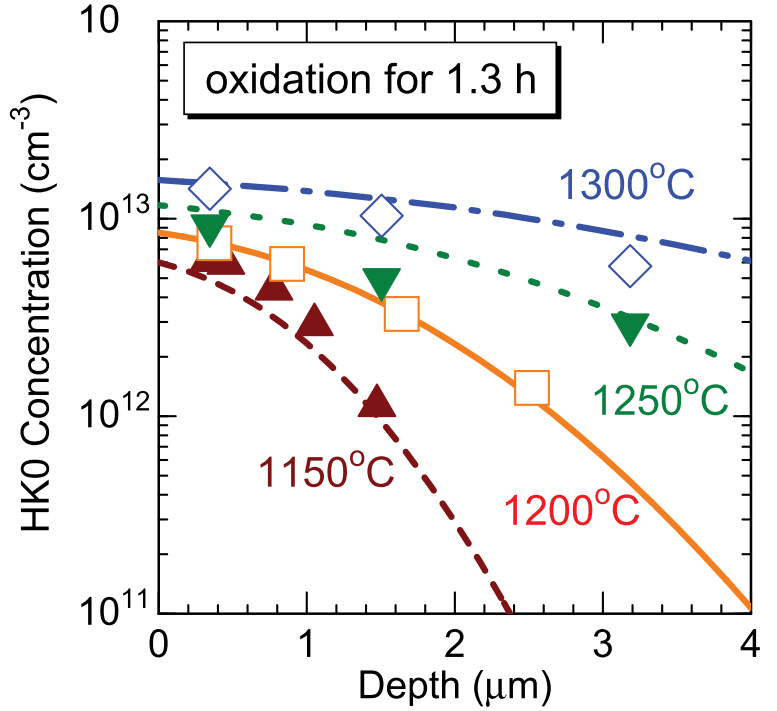

FIG. 2. Depth profiles of HK0 center after oxidation at various temperatures for $1.3 \mathrm{~h}$. Each symbol indicates the experimental data and each line indicates the calculated $n_{\mathrm{I}}$ distribution obtained from Eqs. (1)-(5).

use a simple model that defects (interstitials) diffuse from the $\mathrm{SiO}_{2} / \mathrm{SiC}$ interface into the $\mathrm{SiC}$ bulk during oxidation.

Denoting the concentration of interstitials $\left(\mathrm{C}_{\mathrm{I}}\right.$ or $\left.\mathrm{Si}_{\mathrm{I}}\right)$ by $n_{\mathrm{I}}$ and the diffusion coefficient of the interstitials by $D$, the distribution of interstitials after oxidation is found by solving the diffusion equations

$$
\frac{\partial n_{\mathrm{I}}}{\partial t}=D \cdot \frac{\partial^{2} n_{\mathrm{I}}}{\partial x^{2}}
$$

where the boundary and initial conditions are fixed as

$$
\begin{gathered}
-\left.D \cdot \frac{\partial n_{\mathrm{I}}}{\partial x}\right|_{x=0}=F_{0} \cdot t^{-\alpha}(t \neq 0), \\
\left.n_{\mathrm{I}}\right|_{t=0}=0 .
\end{gathered}
$$

When the calculated results are compared with the experiments, fitting parameters, $D_{\infty}, E_{\mathrm{aD}}, F_{0 \infty}$, and $E_{\mathrm{aF}}$, are obtained from

$$
\begin{gathered}
D=D_{\infty} \cdot \exp \left(-\frac{E_{\mathrm{aD}}}{k T}\right), \\
F_{0}=F_{0 \infty} \cdot \exp \left(-\frac{E_{\mathrm{aF}}}{k T}\right) .
\end{gathered}
$$

The boundary condition, Eq. (2) determines the interstitial emission at the oxidation interface, which is described with $F_{0}$. Because the oxidation rate slows with time, the gradual decrease in flux of the emitted interstitials as oxidation (time) proceeds was taken into account by introducing a damping coefficient $\alpha$. This constant $\left(\alpha=1\right.$ at " $t_{\mathrm{ox}}<0.8 \mathrm{~h}$," $\alpha=0.23$ at " $0.8 \mathrm{~h}<t_{\mathrm{ox}}$ ") was determined from the dependence of the oxidation rate on oxidation time at different oxidation temperatures (not shown, details given elsewhere ${ }^{8}$ ). From Eqs. (4) and (5), $D$ and $F_{0}$ are described as functions of temperature. The fitting parameters, $E_{\mathrm{aD}}$ and $E_{\mathrm{aF}}$, signify the respective activation energies corresponding to the energy 
barriers for the migration and the generation of interstitials. The lines in Fig. 2 indicate the calculated $n_{\mathrm{I}}$ distribution obtained from Eqs. (1)-(5). Fitting parameters determined in this study for the HKO distributions are listed in Table I. Note that the parameters in Table I can be referred only as a guide because of the simplification of the calculation model.

With these parameters, the dependence of the HK0 distribution on oxidation time can also be fitted. Figure 3 shows the depth profiles of the HK0 center after oxidation at $1300^{\circ} \mathrm{C}$ for $1.3-15.9 \mathrm{~h}$. Longer oxidation leads to a deeper HK0 distribution. Here, $5.3 \mathrm{~h} \times 3$ in Fig. 3 (squares and dotted line) indicates that the oxides were removed by hydrofluoric acid treatment after every $5.3 \mathrm{~h}$ of oxidation, which enhances the oxidation speed compared with continuous oxidation because, as mentioned above, the oxidation rate slows with time. Using the same parameters listed in Table I, the calculated results can reproduce the enhancement in HK0 generation by repeated oxidation and oxide removal. At depths shallower than $1 \mu \mathrm{m}$, the calculation results for the $15.9 \mathrm{~h}$ and $5.3 \mathrm{~h} \times 3$ oxidation show slightly lower HK0 concentration than the experimental results. It is, however, very difficult to propose a modified diffusion model to explain the defect concentration near the surface because of the reason mentioned above. Because the calculation (lines) almost fit the experimental data (symbols), the inference is that the origin of the HK0 center must contain interstitials diffusing from the $\mathrm{SiO}_{2}$ interface during oxidation. The origin of the diffusing atoms ( $\mathrm{Si}$ or/and $\mathrm{C}$ ) is discussed in the next sections.

\section{Specific behaviors of the HKO center during oxidation and subsequent Ar annealing}

We found that neither generation nor diffusion of the HK0 center itself occurs by Ar annealing at temperature lower than $1300^{\circ} \mathrm{C}$. Figure 4 shows depth profiles of the HK0 center after oxidation at $1150^{\circ} \mathrm{C}$ for $1.3 \mathrm{~h}$, and after oxidation followed by $\mathrm{Ar}$ annealing at $1150{ }^{\circ} \mathrm{C}$ for $4.3 \mathrm{~h}$. The HK0 distribution did not change by the subsequent annealing at $1150^{\circ} \mathrm{C}$ in an $\mathrm{Ar}$ atmosphere, which indicates that the HK0 center does not diffuse by $\mathrm{Ar}$ annealing at $1150^{\circ} \mathrm{C}$. That HK0 diffuses during oxidation and not during Ar annealing can be explained as a diffusion of interstitials during oxidation generated at the $\mathrm{SiO}_{2} / \mathrm{SiC}$ interface and forming more stable defects, which become the source for the HKO center, and thereby terminating the diffusion. Therefore, rather than a single interstitial, the origin of the HK0 center could be a complex such as an interstitial cluster or an interstitial-impurity complex. From ab initio calculations, the formation of a carbon di-interstitial $\left(\left(\mathrm{C}_{\mathrm{I}}\right)_{2}\right)$ seems to be energetically favorable for a pair of carbon interstitials, ${ }^{24-27}$

TABLE I. Parameter values obtained by fitting of the interstitial profiles calculated based on the diffusion equations (Eqs. (1)-(5)) to experimental HK0 profiles shown in Fig. 1. The top row indicates the " $X$ " in the first column.

\begin{tabular}{lcc}
\hline \hline & $D$ & $F_{0}$ \\
\hline Activation energy $E_{\mathrm{ax}}$ & $3.6 \mathrm{eV}$ & $2.9 \mathrm{eV}$ \\
Coefficient $X_{\infty}$ & $1.4 \mathrm{~cm}^{2} \mathrm{~s}^{-1}$ & $1.4 \times 10^{18} \mathrm{~cm}^{-2} \mathrm{~s}^{\alpha-1}$ \\
\hline \hline
\end{tabular}

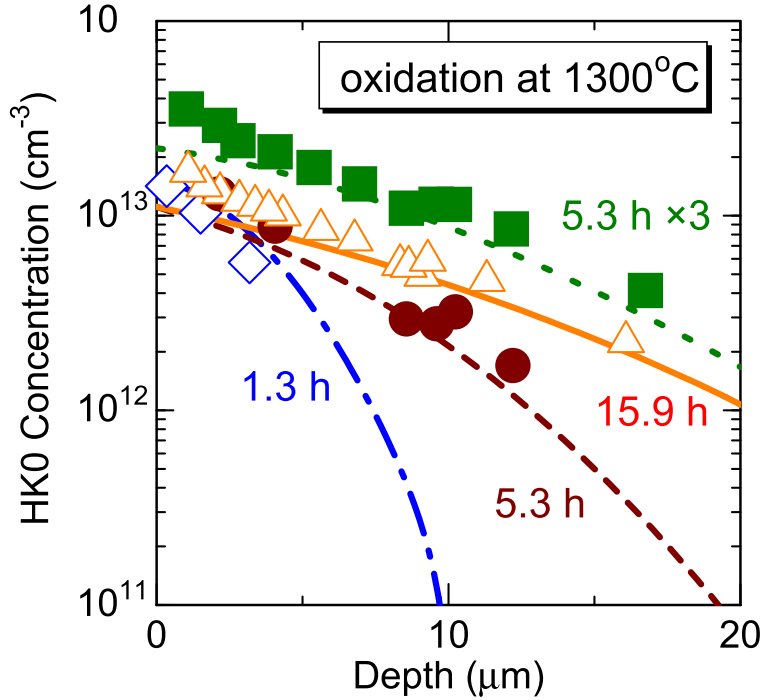

FIG. 3. Depth profiles of the HK0 center after oxidation at $1300^{\circ} \mathrm{C}$ for $1.3-$ $15.9 \mathrm{~h}$. Each symbol indicates the experimental data and each line indicates the calculated $n_{\mathrm{I}}$ distribution obtained from Eqs. (1)-(5).

and that the $\left(\mathrm{C}_{\mathrm{I}}\right)_{2}$ defect forms energy levels at $0.1-1.2 \mathrm{eV}$ above the valence band edge in the lower half of the bandgap of $4 \mathrm{H}-\mathrm{SiC},{ }^{24,26,28}$ which does not conflict with the energy level of the HK0 $\left(E_{\mathrm{V}}+0.79 \mathrm{eV}\right)$ center detected by DLTS. The energy levels of the carbon di-interstitial $\left(\left(\mathrm{C}_{\mathrm{I}}\right)_{2}\right)$ obtained by $a b$ initio calculation ${ }^{24,26,28}$ are shown in Fig. 5, which indicates that the $\left(\mathrm{C}_{\mathrm{I}}\right)_{2}$ is a candidate as source for the HK0 center.

The HK0 center is not stable at temperatures higher than $1400^{\circ} \mathrm{C}$. Figure 6 shows the DLTS spectra of the sample after thermal oxidation at $1300^{\circ} \mathrm{C}$ for $15.9 \mathrm{~h}$, and after the oxidation followed by Ar annealing at $1500^{\circ} \mathrm{C}$ for $2 \mathrm{~h}$. All deep levels including the $\mathrm{HK} 0$ center disappeared after the subsequent $\mathrm{Ar}$ annealing at $1500^{\circ} \mathrm{C}$ (the HK0 center disappears at temperatures over $1400^{\circ} \mathrm{C}$ (Refs. 20, 29, and 30)). The dotted line in Fig. 6 shows the DLTS spectrum of the

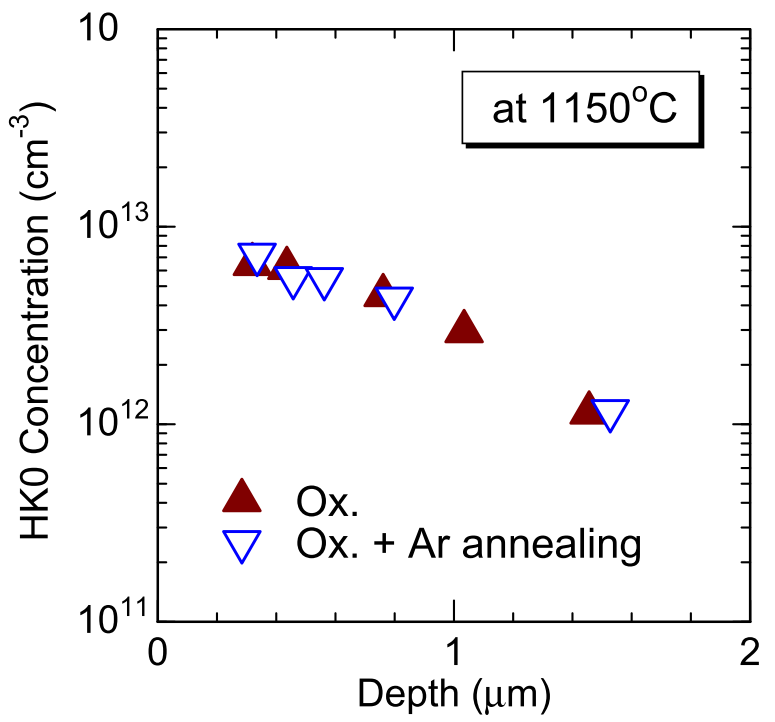

FIG. 4. Depth profiles of the HK0 center after oxidation at $1150^{\circ} \mathrm{C}$ for $1.3 \mathrm{~h}$ (closed triangles), and after the oxidation followed by $\mathrm{Ar}$ annealing at $1150{ }^{\circ} \mathrm{C}$ for $4.3 \mathrm{~h}$ (reverse triangles). 


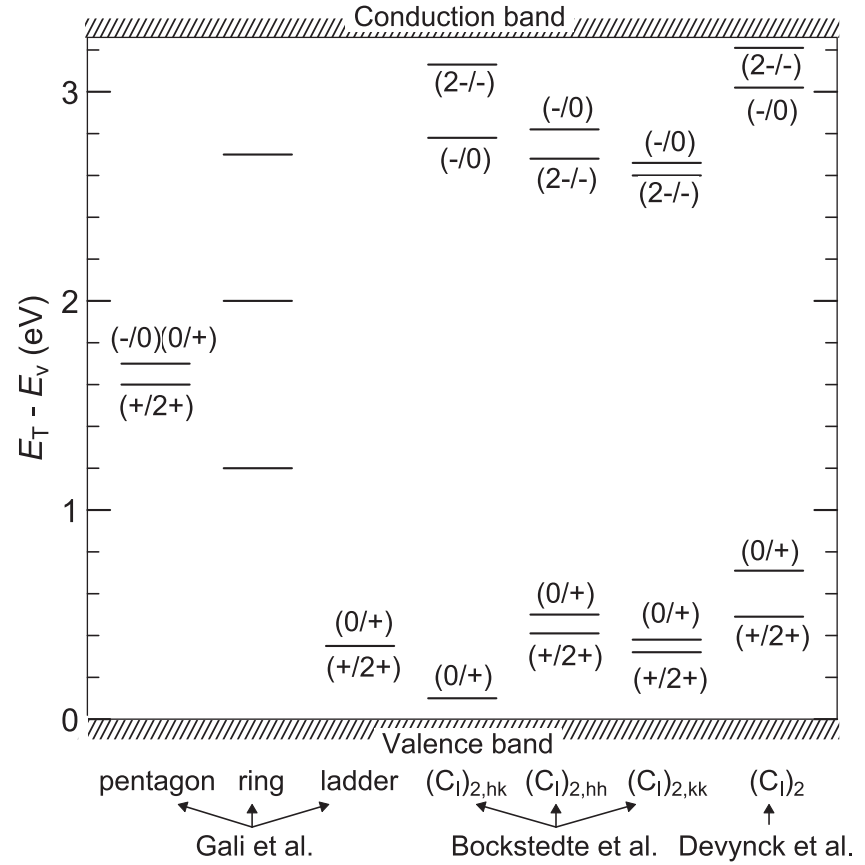

FIG. 5. Energy levels of carbon di-interstitial $\left(\left(\mathrm{C}_{\mathrm{I}}\right)_{2}\right)$ obtained by ab initio calculation. ${ }^{24,26,28}$

sample after thermal oxidation at $1400^{\circ} \mathrm{C}$ for $16.5 \mathrm{~h}$. In contrast with the oxidation at $1300^{\circ} \mathrm{C}$, the HK0 and HK2 centers were not generated by the high-temperature oxidation at $1400^{\circ} \mathrm{C}$. If the origin of the HK0 center is assumed to be an interstitial complex, as previously mentioned, these results (in Fig. 6) indicate that at temperatures over $1400^{\circ} \mathrm{C}$ excess interstitial atoms exist as (i) single interstitials (the origin of HK0 center is dissociated and diffuses at the high temperature), or (ii) more thermally stable defects possessing higher binding energy than that of origin of the HK0 center.

In the last decade, interstitial complexes in $\mathrm{SiC}$ have extensively been investigated by photoluminescence (PL), ${ }^{31-36}$ and these results have been compared with $a b$ initio calculations. ${ }^{25,32,35,37}$ Several kinds of C-related defects have been suggested to exist in electron-irradiated $4 \mathrm{H}-\mathrm{SiC}$ and $6 \mathrm{H}-\mathrm{SiC}^{31-37}$ The identified PL signals are: T1 (a center),

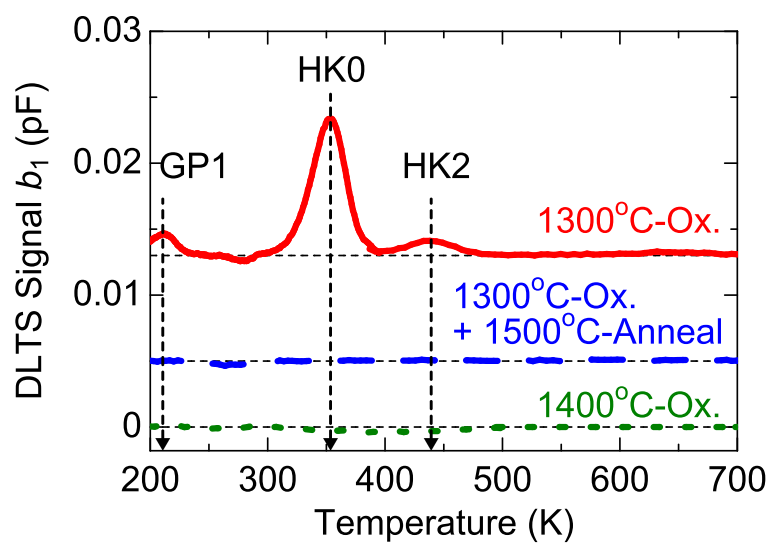

FIG. 6. DLTS spectra of the p-type $4 \mathrm{H}-\mathrm{SiC}$ after thermal oxidation at $1300^{\circ} \mathrm{C}$ for $15.9 \mathrm{~h}$ (solid line), and after the oxidation followed by $\mathrm{Ar}$ annealing at $1500^{\circ} \mathrm{C}$ for $2 \mathrm{~h}$ (dashed line). DLTS spectrum of the sample after thermal oxidation at $1400^{\circ} \mathrm{C}$ for $16.5 \mathrm{~h}$ is also shown as a dotted line.
$\mathrm{T} 2 / \mathrm{T} 3$ (b center), and $\mathrm{T} 4$ (c center) centers as $\left(\mathrm{C}_{2}\right)_{\mathrm{Si}},{ }^{33-36} \mathrm{U}$ center $(471.8 \mathrm{~nm}$ zero phonon line $(\mathrm{ZPL})$ in $4 \mathrm{H}-\mathrm{SiC})$ as $\left(\mathrm{C}_{3}\right)_{\mathrm{Si}}{ }_{3,3,33,36} \mathrm{G}$ center $(493.5 \mathrm{~nm} \mathrm{ZPL}$ in $4 \mathrm{H}-\mathrm{SiC}$ ) as $\left(\left(\mathrm{C}_{2}\right)_{\mathrm{Si}}\right)_{2},{ }^{33,36} \mathrm{Z}$ center (maybe $599.3 \mathrm{~nm} \mathrm{ZPL}$ in $4 \mathrm{H}-\mathrm{SiC}$ ) as $\left(\mathrm{C}_{\mathrm{I}}\right)_{2}{ }^{32,33}$ The dissociation energy was calculated to be about $5.5 \mathrm{eV}$ for $\left(\mathrm{C}_{\mathrm{I}}\right)_{2},{ }^{24-26} 3.6 \mathrm{eV}$ for $\left(\mathrm{C}_{2}\right)_{\mathrm{Si}},{ }^{25} 5.8 \mathrm{eV}$ for $\left(\mathrm{C}_{3}\right)_{\mathrm{Si}},{ }^{25}$ and $6.7 \mathrm{eV}$ for $\left(\left(\mathrm{C}_{2}\right)_{\mathrm{Si}}\right)_{2},{ }^{25}$ which is consistent with relatively high thermal stability of the defect centers observed in PL. ${ }^{33}$ Note that post-irradiation annealing behaviors of the $\mathrm{U}$ center (ZPL at $471.8 \mathrm{~nm}$ in $4 \mathrm{H}-\mathrm{SiC}$ ) and the $\mathrm{G}$ center ( $\mathrm{ZPL}$ at $493.5 \mathrm{~nm}$ in $4 \mathrm{H}-\mathrm{SiC}$ ) are similar with that of the HK0 center detected by DLTS in this study. The U/G centers appear after annealing at $1100^{\circ} \mathrm{C} / 950^{\circ} \mathrm{C}$, remain at $1300^{\circ} \mathrm{C} / 1200^{\circ} \mathrm{C}$, and disappear at $1400^{\circ} \mathrm{C} / 1300^{\circ} \mathrm{C}$ (all annealing is $30 \mathrm{~min}$ long), ${ }^{33}$ whereas the HK0 center appears after annealing at $950^{\circ} \mathrm{C}$, remains at $1300^{\circ} \mathrm{C}$, and disappears at $1400^{\circ} \mathrm{C}$.

Therefore, the origin of the HK0 center could be $\left(\mathrm{C}_{\mathrm{I}}\right)_{2}$, $\left(\mathrm{C}_{3}\right)_{\mathrm{Si}}$, or $\left(\left(\mathrm{C}_{2}\right)_{\mathrm{Si}}\right)_{2}$, which is formed from single carbon interstitials generated and diffusing during oxidation at lower than $1300^{\circ} \mathrm{C} .\left(\mathrm{C}_{3}\right)_{\mathrm{Si}}$ and $\left(\left(\mathrm{C}_{2}\right)_{\mathrm{Si}}\right)_{2}$ can be formed when the diffusing carbon atoms occupy silicon vacancies or displace silicon atoms.

\section{B. Deep levels generated by electron irradiation}

As described in the last section, the origin of the HK0 center could be carbon-related complexes. To obtain more insights of the origin, we investigated p-type samples irradiated with $150 \mathrm{keV}$ electrons (fluence: $1.0 \times 10^{17} \mathrm{~cm}^{-2}$ ), where displacement of only the carbon atoms occurs. ${ }^{9,12}$ Figure 7 shows DLTS spectra of the samples after electron irradiation and after subsequent oxidation at $11500^{\circ} \mathrm{C}$ for 1.3 h. UK1 $\left(E_{\mathrm{V}}+0.49 \mathrm{eV}\right),{ }^{20} \mathrm{HS} 2\left(E_{\mathrm{V}}+0.63 \mathrm{eV}\right),{ }^{9,20} \mathrm{UK} 2$ $\left(E_{\mathrm{V}}+0.71 \mathrm{eV}\right),{ }^{20}$ and HK4 $\left(E_{\mathrm{V}}+1.4 \mathrm{eV}\right)^{20}$ centers were detected after electron irradiation. The HS2 center has been reported to appear after electron irradiation with the energy of $116 \mathrm{keV}-9 \mathrm{MeV},{ }^{9,20}$ whereas the UK1 and UK2 centers appear with $160 \mathrm{keV}-400 \mathrm{keV}$ electrons. ${ }^{20}$ The HK4 center has also been observed in as-grown samples. ${ }^{20}$ As evident in Fig. 7 , after subsequent oxidation at $1150^{\circ} \mathrm{C}$ for $1.3 \mathrm{~h}$, the HS2 and HK4 centers disappear, and the HK0 and HK2 centers emerge. The HK0 and HK2 centers cannot originate

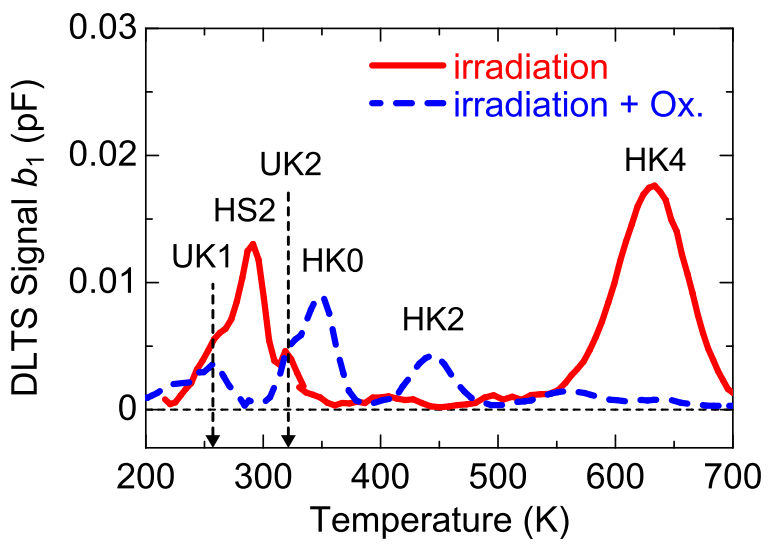

FIG. 7. DLTS spectra of the p-type $4 \mathrm{H}-\mathrm{SiC}$ irradiated with $150 \mathrm{keV}$ electrons (solid line), and after electron irradiation followed by oxidation at $1150^{\circ} \mathrm{C}$ for $1.3 \mathrm{~h}$ (dashed line). 

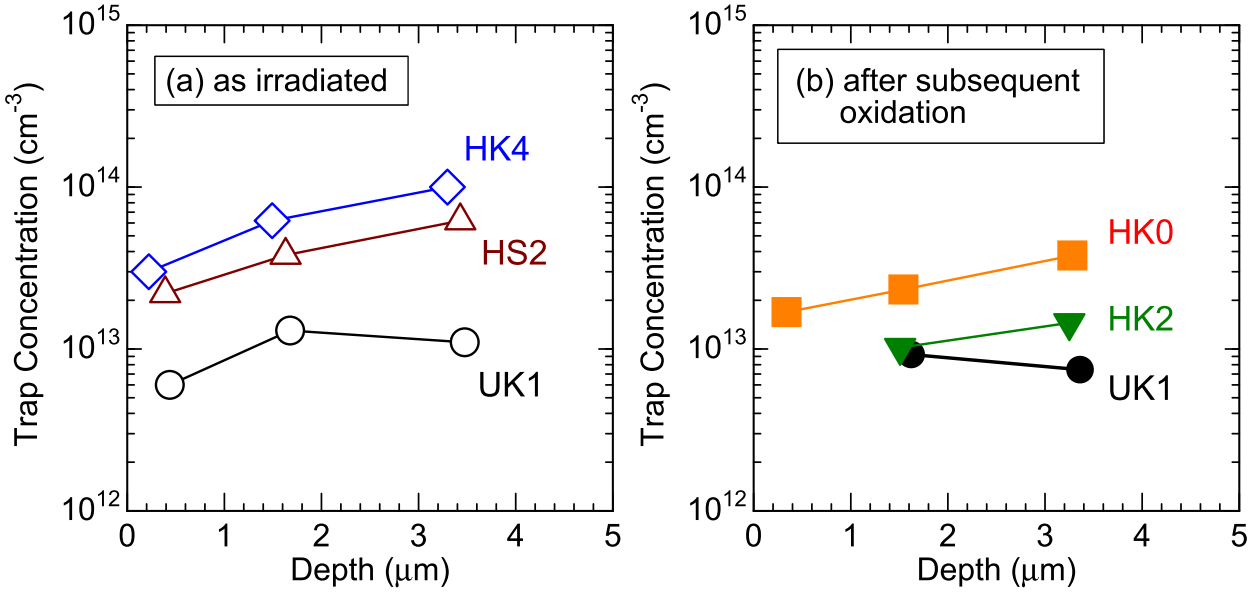

FIG. 8. Depth profiles of (a) UK1 (circles), HS2 (triangles), and HK4 (rhombuses) centers in the p-type $4 \mathrm{H}-\mathrm{SiC}$ after electron irradiation $\left(150 \mathrm{keV}, 1.0 \times 10^{17} \mathrm{~cm}^{-2}\right)$, and (b) HK0 (squares) and HK2 (reverse triangles) centers after irradiation followed by thermal oxidation at $1150^{\circ} \mathrm{C}$ for $1.3 \mathrm{~h}$. from a single interstitial because the HK0 and HK2 centers were not detected in as-irradiated samples but in samples after subsequent oxidation (or Ar annealing ${ }^{20}$ ).

Figure 8 shows depth profiles of (a) UK1, HS2, and $\mathrm{HK} 4$ centers in the p-type $4 \mathrm{H}$-SiC after electron irradiation, and (b) HK0 and HK2 centers after the irradiation followed by thermal oxidation at $1150^{\circ} \mathrm{C}$ for $1.3 \mathrm{~h}$. The $\mathrm{HK} 0$ center after electron irradiation followed by thermal oxidation shows higher concentration and is distributed to a deeper region compared with the HK0 center after only thermal oxidation (Fig. 2), which means that irradiation-induced damage is the main cause of the HK0 generation in these samples. Figure 9 shows depth profiles of the HK0 center in the samples after electron irradiation followed by thermal oxidation at different temperatures for $1.3 \mathrm{~h}$. The HK0 distribution in the samples after electron irradiation followed by thermal oxidation is almost independent of oxidation temperature, which also means that the HK0 center generated by thermal oxidation is negligible compared with the HK0 generation caused by irradiation damage.

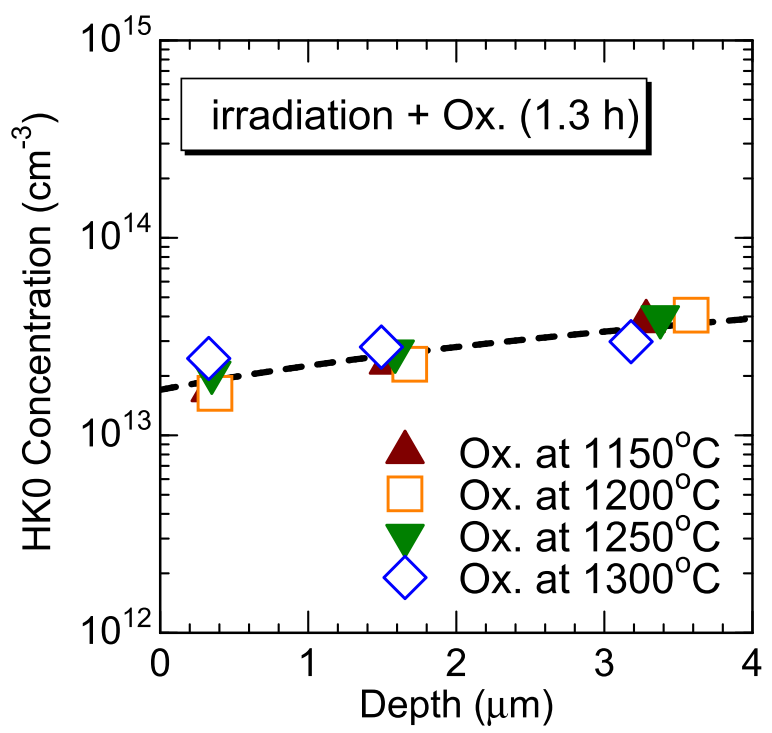

FIG. 9. Depth profiles of the HK0 center in the p-type 4H-SiC after electron irradiation $\left(150 \mathrm{keV}, 1.0 \times 10^{17} \mathrm{~cm}^{-2}\right)$ followed by thermal oxidation at different temperatures for $1.3 \mathrm{~h}$.
The other four deep levels, UK1, HS2, HK2, and HK4, show similar distribution to the HK0 distribution (Fig. 8), which may indicate that these also originate from irradiation-induced damage (related to $\mathrm{C}_{\mathrm{I}}$ or/and $\mathrm{V}_{\mathrm{C}}$ ). The HK0 and HK2 centers were detected only after postirradiation annealing, whereas the UK1, HS2, and HK4 centers were detected just after electron irradiation. Therefore, the origin of the HK0 center (and the HK2 center) should be a carbon-related complex defect (and not single interstitial), which is consistent with the results obtained in the last section.

\section{Deep levels generated by $\mathrm{C}^{+}$or $\mathrm{Si}^{+}$implantation}

Investigation on the deep levels in $\mathrm{C}^{+}$- or $\mathrm{Si}^{+}$-implanted samples must be helpful for clarifying the origin of the deep levels. Therefore, $\mathrm{C}^{+}$or $\mathrm{Si}^{+}$implantation was performed on the p-type $\mathrm{SiC}$ epilayers, followed by Ar annealing. Figure 10 shows DLTS spectra of the p-type $4 \mathrm{H}-\mathrm{SiC}$ after $\mathrm{C}^{+}$implantation followed by Ar annealing at $1300^{\circ} \mathrm{C}$ (the solid line is the signal obtained near the surface $(<1 \mu \mathrm{m})$, and the dashed line in a deeper region) and at $1500{ }^{\circ} \mathrm{C}$ (dotted line). In the $\mathrm{C}^{+}$-implanted samples, the same deep levels, UK1, UK2, HK0, and HK2 centers, are observed as those observed in the electron-irradiated samples (Fig. 7) that must be related to the carbon displacement as discussed above. When the

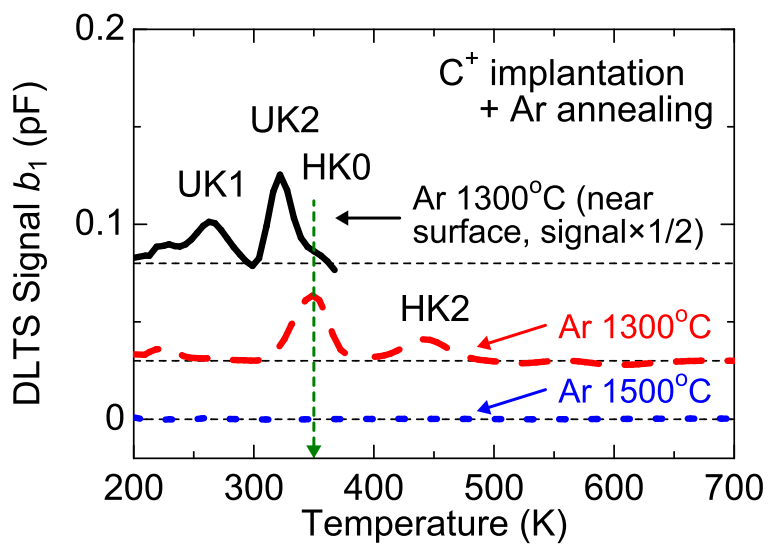

FIG. 10. DLTS spectra of the p-type $4 \mathrm{H}-\mathrm{SiC}$ after $\mathrm{C}+$ implantation followed by $\mathrm{Ar}$ annealing at $1300^{\circ} \mathrm{C}$ (solid line is the signal obtained near the surface $(<1 \mu \mathrm{m})$, and dashed line in the deeper region) and $1500^{\circ} \mathrm{C}$ (dotted line). 


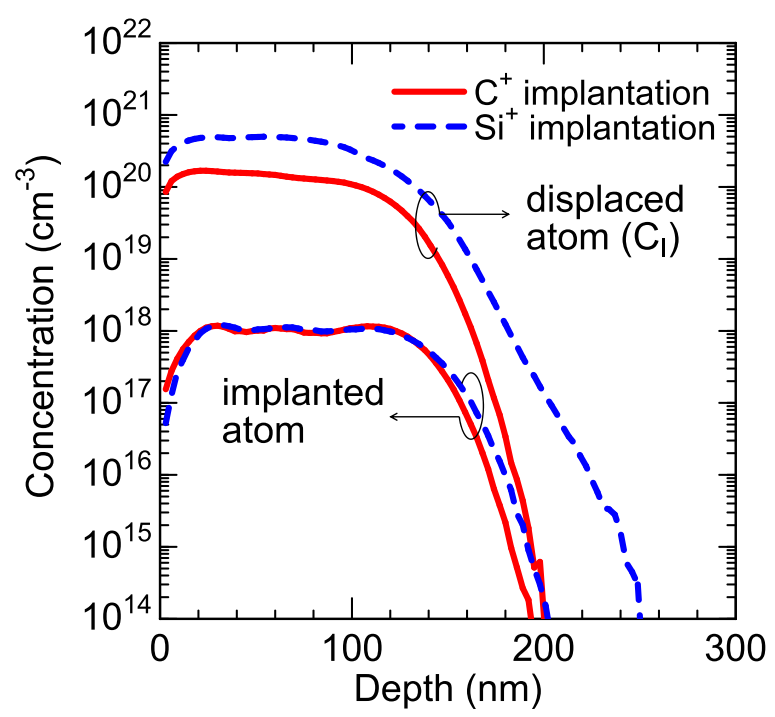

FIG. 11. Depth profiles of implanted atoms and carbon interstitials after $\mathrm{C}^{+}$ or $\mathrm{Si}^{+}$implantation (total dose: $1 \times 10^{13} \mathrm{~cm}^{-2}$ ) simulated by SRIM code.

temperature of the subsequent annealing was $1500^{\circ} \mathrm{C}$, no DLTS peaks could be observed as indicated in Fig. 10 by the dotted line. This is consistent with the results obtained in the oxidized samples where all DLTS peaks disappeared after annealing over $1400{ }^{\circ} \mathrm{C}$ (Fig. 6). For $\mathrm{Si}^{+}$implantation, a similar behavior for the deep levels was observed (not shown).

Figure 11 shows the depth profiles of implanted atoms and $\mathrm{C}_{\mathrm{I}}$ generated by the collision of implanted ions, just after implantation, which were simulated using a SRIM code; ${ }^{38}$ SRIM is an acronym for stopping and range of ions in matter. The $\mathrm{C}_{\mathrm{I}}$ concentration in the $\mathrm{Si}^{+}$-implanted samples is higher than that in the $\mathrm{C}^{+}$-implanted samples due to the higher energy of $\mathrm{Si}^{+}$implantation $\left(10-50 \mathrm{keV}\right.$ for $\mathrm{C}^{+}$implantation and $25-110 \mathrm{keV}$ for $\mathrm{Si}^{+}$implantation) and larger mass of $\mathrm{Si}^{+}$. The distribution of $\mathrm{V}_{\mathrm{C}} / \mathrm{V}_{\mathrm{S}_{\mathrm{i}}}$ is almost the same as that of $\mathrm{C}_{\mathrm{I}} / \mathrm{Si}_{\mathrm{I}}$ in the simulation (the difference is within $1 \mathrm{~nm}$, not shown), which means that carbon atoms/silicon atoms are not knocked far away from their original positions by collisions with implanted atoms. In contrast, the distribution of $\mathrm{Si}_{\mathrm{I}}$ and $\mathrm{V}_{\mathrm{S}_{\mathrm{i}}}$ shows a little lower concentration $(\sim 70 \%)$ than that of $\mathrm{C}_{\mathrm{I}}$ (and $\mathrm{V}_{\mathrm{C}}$ ) because of the higher displacement energy of $35 \mathrm{eV}$ for a silicon atom compared with $21 \mathrm{eV}$ for a carbon atom. ${ }^{39}$ Note that a large amount of the interstitials and vacancies generated by implantation bombardment should recombine during the subsequent $\mathrm{Ar}$ annealing because these are located closely to each other after implantation.

Figure 12 shows the depth profiles of deep levels in the (a) $\mathrm{C}^{+}$- or (b) $\mathrm{Si}^{+}$-implanted samples followed by $\mathrm{Ar}$ annealing at $1300{ }^{\circ} \mathrm{C}$ for $20 \mathrm{~min}$, respectively. Depth profiles of carbon interstitials just after $\mathrm{C}^{+}$or $\mathrm{Si}^{+}$implantation simulated by the SRIM code are also shown as a solid line in the same figures. The deep levels can be categorized into two groups; the UK1 and UK2 centers as group A, and the HK0 and HK2 centers as group B. Group A has low diffusivity, the distribution of which is not much different from that of $\mathrm{C}_{\mathrm{I}}$ (or the other intrinsic defects just after ion implantation) simulated by the SRIM code (the real tail region of the $\mathrm{C}_{\mathrm{I}}$ distribution should spread to a deeper region because the SRIM code assumes a completely amorphous material as a target). Therefore, the UK1 and UK2 centers could originate from immobile defect(s) induced by collision of implanted atoms (e.g., vacancy and complex). The similarity in the depth profiles of the UK1 and UK2 centers probably reflects that (i) these originate from the same defect and correspond to different charge states (thermal stability of the UK1 and UK2 centers is $\operatorname{similar}^{20}$ ), or (ii) the origin of these is different but simply shows a similar distribution (simulation results show similar distributions for $\mathrm{V}_{\mathrm{C}}, \mathrm{C}_{\mathrm{I}}, \mathrm{V}_{\mathrm{S}_{\mathrm{i}}}$, and $\mathrm{Si}_{\mathrm{I}}$ just after the implantation, as mentioned above). In contrast, group B (HK0 and HK2) is distributed to a much deeper region after $\mathrm{Ar}$ annealing at $1300^{\circ} \mathrm{C}$ than the depth profile of implanted atoms, indicating that the origin of these contains a mobile defect such as $\mathrm{C}_{\mathrm{I}}$ and $\mathrm{Si}_{\mathrm{I}}$. The concentration of the HK0 center is about three times higher than that of the HK2 center in the whole monitored area. In other words, the concentration of the HK0 center is different from that of the HK2 center, but the diffusion coefficient of HK0 is the same as that of the $\mathrm{HK} 2$, indicating that these could contain the same defect but form different configurations, like $\mathrm{C}_{\mathrm{I}},\left(\mathrm{C}_{\mathrm{I}}\right)_{2}$, $\left(\mathrm{C}_{2}\right)_{\mathrm{Si}},\left(\mathrm{C}_{3}\right)_{\mathrm{Si}}$, and $\left(\left(\mathrm{C}_{2}\right)_{\mathrm{Si}}\right)_{2}$.

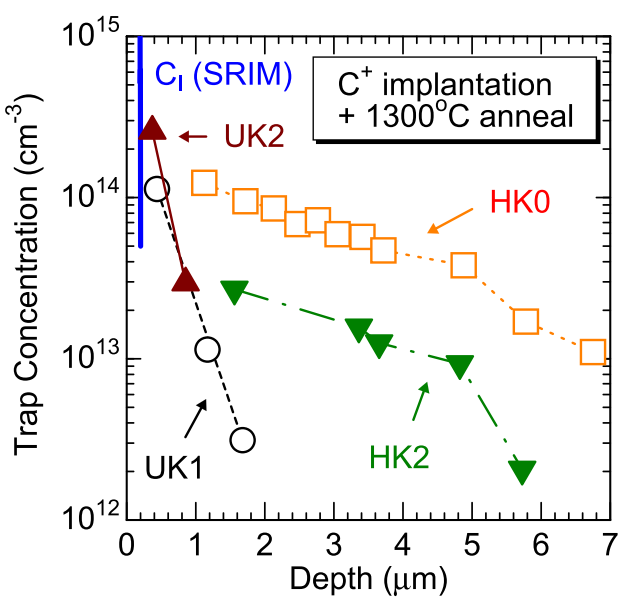

(a)

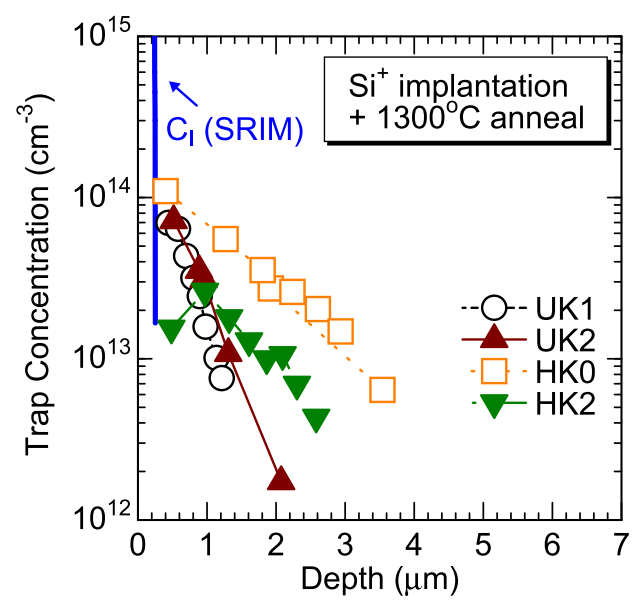

(b)
FIG. 12. Depth profiles of deep levels in the p-type $4 \mathrm{H}$-SiC after (a) $\mathrm{C}^{+}$or (b) $\mathrm{Si}^{+}$ implantation (dose: $1 \times 10^{13} \mathrm{~cm}^{-2}$ ) followed by $\mathrm{Ar}$ annealing at $1300^{\circ} \mathrm{C}$ for 20 min. A depth profile of carbon interstitials just after $\mathrm{C}^{+}$implantation simulated by SRIM code is also shown as a solid line. 


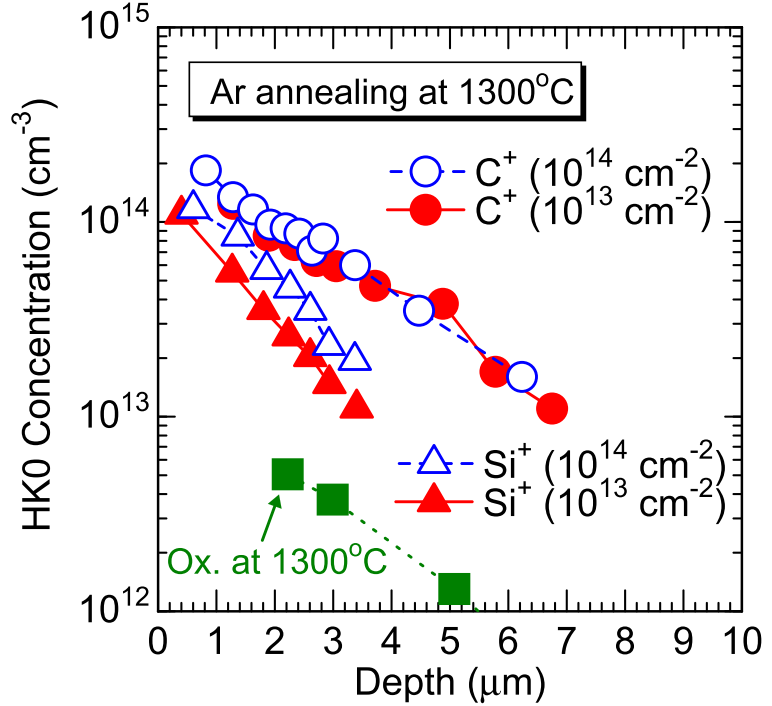

FIG. 13. Depth profiles of HK0 center in the p-type $4 \mathrm{H}-\mathrm{SiC}$ after $\mathrm{C}^{+}$ (circles) and $\mathrm{Si}^{+}$(triangles) implantation followed by $\mathrm{Ar}$ annealing at $1300^{\circ} \mathrm{C}$ for $20 \mathrm{~min}$. Depth profile of HK0 center in the sample oxidized at $1300^{\circ} \mathrm{C}$ for $20 \mathrm{~min}$ is also shown as square symbols.

Figure 13 shows plots of the depth profiles for the HK0 center in the samples after implantation with either $\mathrm{C}^{+}$ (circles) or $\mathrm{Si}^{+}$(triangles) followed by $\mathrm{Ar}$ annealing at $1300^{\circ} \mathrm{C}$ for $20 \mathrm{~min}$. The $\mathrm{HK} 0$ concentration after implantation is clearly higher than that after thermal oxidation at $1300^{\circ} \mathrm{C}$ for $20 \mathrm{~min}$ (closed squares, dotted line). This should come as a result of the high amounts of interstitials near the surface region induced by ion implantation, either $\mathrm{C}^{+}$or $\mathrm{Si}^{+}$. The HK0 center in $\mathrm{C}^{+}$-implanted samples is distributed to a deeper region with higher concentration compared with that in $\mathrm{Si}^{+}$-implanted samples, indicating that the origin of the $\mathrm{HK} 0$ center is $\mathrm{C}_{\mathrm{I}}$-related defects. If the HK0 center originates from other defects (e.g., $\mathrm{Si}_{\mathrm{I}}$ ) generated by implantation bombardment (some of the defects might not recombine and thus diffuse during Ar annealing), the HKO concentration in the
$\mathrm{Si}^{+}$-implanted samples must be higher than that in the $\mathrm{C}^{+}$implanted samples because the amount of displaced atoms in the $\mathrm{Si}^{+}$-implanted samples is higher than that in the $\mathrm{C}^{+}$implanted samples under this implantation condition, as calculated by the SRIM code (Fig. 11). Therefore, the HK0 in the $\mathrm{C}^{+}$-implanted samples can be determined mainly by the diffusion of implanted carbon atoms (excess carbon atoms), whereas the distribution in the $\mathrm{Si}^{+}$-implanted samples mainly by diffusion of $\mathrm{C}_{\mathrm{I}}$ generated by implantation bombardment. We also investigated the dependence of the HK0 distribution on implantation dose. In Fig. 13, closed/open symbols indicate the HK0 distribution for doses $1 \times 10^{13} \mathrm{~cm}^{-2} / 1$ $\times 10^{14} \mathrm{~cm}^{-2}$. The HK0 concentration in the samples implanted at the higher dose is almost the same or slightly higher than that at the lower dose, suggesting that the amount of $\mathrm{C}_{\mathrm{I}}$ diffusion is not much different in the two samples $\left(1 \times 10^{13} \mathrm{~cm}^{-2} / 1 \times 10^{14} \mathrm{~cm}^{-2}\right.$ dose $)$. Because too high a concentration of $\mathrm{C}_{\mathrm{I}}$ defects (e.g., $1 \times 10^{18} \mathrm{~cm}^{-3}$ ) is thermodynamically unfavorable, this concentration should be reduced to a certain level during Ar annealing by either conversion to other defects or diffusion to the sample surface.

\section{DISCUSSION}

In this study, eight deep levels, GP1 $\left(E_{\mathrm{V}}+0.46 \mathrm{eV}\right)$, $\mathrm{D}\left(E_{\mathrm{V}}+0.63 \mathrm{eV}\right),{ }^{17-20} \mathrm{HS} 2\left(E_{\mathrm{V}}+0.63 \mathrm{eV}\right),{ }^{9,20} \mathrm{HK} 4\left(E_{\mathrm{V}}\right.$ $+1.4 \mathrm{eV}),{ }^{20} \mathrm{UK} 1\left(E_{\mathrm{V}}+0.49 \mathrm{eV}\right),{ }^{20} \mathrm{UK} 2\left(E_{\mathrm{V}}+0.71 \mathrm{eV}\right),{ }^{20}$ HK0 $\left(E_{\mathrm{V}}+0.79 \mathrm{eV}\right),{ }^{20}$ and HK2 $\left(E_{\mathrm{V}}+0.98 \mathrm{eV}\right)^{20}$ centers, were detected in p-type $4 \mathrm{H}-\mathrm{SiC}$; a summary is given in Table II. The GP1 center was occasionally detected in asgrown samples (Fig. 1) and disappeared after oxidation at $1400^{\circ} \mathrm{C}$ (Fig. 6) or Ar annealing at $1440{ }^{\circ} \mathrm{C}$ (not shown). This type of deep level was not found in previous reports. The $\mathrm{D}$ center, which has been attributed to $\mathrm{B}_{\mathrm{Si}}-\mathrm{V}_{\mathrm{C}},{ }^{18,21,22}$ was detected in all as-grown samples and disappeared after thermal oxidation (Fig. 1). $\mathrm{V}_{\mathrm{C}}$ in the $\mathrm{D}$ center will be filled with diffusing $C_{I}$ emitted from the oxidizing interface. The HS2 and HK4 centers were generated by electron irradiation and disappeared after thermal oxidation at $1150{ }^{\circ} \mathrm{C}$ (Fig. 7).

TABLE II. Deep levels observed in p-type 4H-SiC and the condition for generation and elimination. The suspected origins are also shown.

\begin{tabular}{|c|c|c|c|c|}
\hline Label & $E_{\mathrm{T}}-E_{\mathrm{V}}(\mathrm{eV})$ & Generated by & Eliminated by & Origin (speculation) \\
\hline GP1 & 0.46 & & $1440^{\circ} \mathrm{C} \mathrm{Ar}$ annealing & Unknown \\
\hline \multicolumn{5}{|c|}{ As-grown } \\
\hline $\mathrm{D}$ & 0.63 & & $1150^{\circ} \mathrm{C}$ oxidation & $\mathrm{B}_{\mathrm{Si}}-\mathrm{V}_{\mathrm{C}}^{18,21,22}$ \\
\hline HS2 & 0.63 & & $\begin{array}{l}1150^{\circ} \mathrm{C} \text { oxidation or } \\
1350^{\circ} \mathrm{C} \mathrm{Ar} \text { annealing }{ }^{20}\end{array}$ & \multirow{3}{*}{ C-related } \\
\hline & & Electron irradiation & & \\
\hline HK4 & 1.4 & & $\begin{array}{l}1150^{\circ} \mathrm{C} \text { oxidation or } \\
1550^{\circ} \mathrm{C} \mathrm{Ar} \text { annealing }\end{array}$ & \\
\hline UK1 & 0.49 & Electron irradiation or & \multirow[t]{2}{*}{$1440^{\circ} \mathrm{C}$ Ar annealing } & C-related and \\
\hline UK2 & 0.71 & $\mathrm{C}^{+} / \mathrm{Si}^{+}$implantation & & immobile \\
\hline HK0 & 0.79 & $\begin{array}{c}\text { Oxidation or } \\
\text { electron irradiation or } \\
\mathrm{C}^{+} / \mathrm{Si}^{+} \text {implantation }\end{array}$ & $1400^{\circ} \mathrm{C} \mathrm{Ar}$ annealing & $\begin{array}{l}\left(\mathrm{C}_{\mathrm{I}}\right)_{2} \text { or } \\
\left(\mathrm{C}_{3}\right)_{\mathrm{Si}} \text { or } \\
\left(\left(\mathrm{C}_{2}\right)_{\mathrm{Si}}\right)_{2}\end{array}$ \\
\hline
\end{tabular}


The HS2 and HK4 centers should be related to $\mathrm{C}_{\mathrm{I}}$ or/and $\mathrm{V}_{\mathrm{C}}$, because depth profiles for these after irradiation with $150 \mathrm{keV}$ electrons, causing displacement of only carbon atoms, seem to reflect the irradiation damage (Fig. 8). The UK1 and UK2 centers were generated by electron irradiation (Fig. 7) or $\mathrm{C}^{+} / \mathrm{Si}^{+}$implantation (Fig. 10), which remained after $\mathrm{Ar}$ annealing at $1300^{\circ} \mathrm{C}$ (Fig. 12) but eliminated at $1440{ }^{\circ} \mathrm{C}$ (not shown). The depth profiles of the UK1 and UK2 centers followed irradiation damage (Fig. 8) or $\mathrm{C}^{+} / \mathrm{Si}^{+}$ implantation damage (Fig. 12), and did not change after $\mathrm{Ar}$ annealing at $1300^{\circ} \mathrm{C}$ (Fig. 12), indicating that these originate from carbon-related and immobile defects.

The HK0 and HK2 centers must be related to interstitials (not vacancy) because (i) the HK0 distribution after oxidation can be fitted by the interstitial distribution calculated from the diffusion equations (1)-(5) (Figs. 2 and 3), and (ii) these centers are distributed to much deeper regions compared with the other deep levels (UK1 and UK2) after $\mathrm{C}^{+}$or $\mathrm{Si}^{+}$implantation followed by Ar annealing (Fig. 12). In addition, the HK0 and HK2 centers must be carbon-related defects (not silicon-related defect) because (i) these are generated by irradiation with $150 \mathrm{keV}$ electrons, and (ii) higher concentrations of the HK0 and HK2 centers are observed in $\mathrm{C}^{+}$-implanted samples than in $\mathrm{Si}^{+}$-implanted samples (Fig. 13); nevertheless, the amount of displaced atoms by $\mathrm{Si}^{+}$implantation is higher than that by $\mathrm{C}^{+}$implantation. Furthermore, the HK0 and HK2 centers are inferred to be complex defects (not single $\mathrm{C}_{\mathrm{I}}$ ) from the results that (i) the HK0 center is generated (through diffusion of carbon interstitials) during thermal oxidation, but does not diffuse by subsequent $\mathrm{Ar}$ annealing at the same temperature (Fig. 4), and (ii) the HK0 and HK2 centers are not detected just after irradiation, but detected after the subsequent annealing (Fig. 7). From these results, the origin of the HK0 center should be a complex that includes carbon interstitial(s) like $\left(\mathrm{C}_{\mathrm{I}}\right)_{2},\left(\mathrm{C}_{3}\right)_{\mathrm{Si}}$, or $\left(\left(\mathrm{C}_{2}\right)_{\mathrm{Si}}\right)_{2}$. This defect should decompose or be converted to other defects at temperatures over $1400{ }^{\circ} \mathrm{C}$ (Figs. 6 and 10). PL signals corresponding to these $\mathrm{C}_{\mathrm{I}}$-related complexes have been reported in electronirradiated $\mathrm{SiC}^{25,31-37}$ thermal stability of which is similar to that of the HK0 center.

We speculate that point defects during thermal oxidation should behave as follows. Carbon interstitials (and also silicon interstitials) are generated at the $\mathrm{SiO}_{2} / \mathrm{SiC}$ interface and diffuse into $\mathrm{SiC}$ bulk during thermal oxidation. The concentration of silicon interstitials in SiC bulk after oxidation is much lower than that of carbon interstitials because of the low diffusivity. ${ }^{40,41}$ Many diffusing carbon interstitials recombine with carbon vacancies, leading to a reduction in $\mathrm{Z}_{1 / 2}$ centers. Other carbon interstitials combine with one another (or combine and occupy silicon vacancies) and form $\mathrm{C}_{\mathrm{I}}$-related complexes (the origin of HK0 center) during oxidation when the oxidation temperature is below $1300^{\circ} \mathrm{C}$. Subsequent $\mathrm{Ar}$ annealing at over $1400^{\circ} \mathrm{C}$ decomposes the source of the HK0 center (and/or form more thermally stable defects). For oxidation at over $1400^{\circ} \mathrm{C}, \mathrm{C}_{\mathrm{I}}$ defects do not combine with others (or form very thermally stable defects) during oxidation, resulting in no DLTS peaks in the lower half of the bandgap in $4 \mathrm{H}-\mathrm{SiC}$.

\section{CONCLUSION}

We sought to reveal the origins of the deep levels observed in p-type $4 \mathrm{H}-\mathrm{SiC}$ after thermal oxidation, especially $\mathrm{HK} 0\left(E_{\mathrm{V}}+0.79 \mathrm{eV}\right)$ and $\mathrm{HK} 2\left(E_{\mathrm{V}}+0.98 \mathrm{eV}\right)$ centers, by comparing deep levels observed in oxidized, electronirradiated, and $\mathrm{C}^{+}$- or $\mathrm{Si}^{+}$-implanted samples. The HK0 and HK2 centers are generated by thermal oxidation, electron irradiation, or $\mathrm{C}^{+} / \mathrm{Si}^{+}$implantation, and eliminated by $\mathrm{Ar}$ annealing at temperatures over $1400^{\circ} \mathrm{C}$. From this behavior of the HKO and HK2 centers, the origin of these centers is thought to be from a complex that include carbon interstitial(s) like $\left(\mathrm{C}_{\mathrm{I}}\right)_{2},\left(\mathrm{C}_{3}\right)_{\mathrm{Si}}$, or $\left(\left(\mathrm{C}_{2}\right)_{\mathrm{Si}}\right)_{2}$. PL signals corresponding to these $\mathrm{C}_{\mathrm{I}}$-related complexes have been reported in electron-irradiated $\mathrm{SiC}$, the thermal stability of which is similar to that of the HK0 center. Following all results in this study, we could describe the behavior of the point defects (and deep levels) in $\mathrm{SiC}$ during oxidation and during subsequent Ar annealing.

\section{ACKNOWLEDGMENTS}

This work was supported by the Funding Program for World-Leading Innovative R\&D on Science and Technology (FIRST Program) and a Grant-in-Aid for Scientific Research (21226008 and 80225078) from the Japan Society for the Promotion of Science.

${ }^{1}$ D. V. Lang and C. H. Henry, Phys. Rev. Lett. 35, 1525 (1975).

${ }^{2}$ T. Dalibor, G. Pensl, H. Matsunami, T. Kimoto, W. J. Choyke, A. Schöner, and N. Nordell, Phys. Status Solidi A 162, 199 (1997).

${ }^{3}$ P. B. Klein, B. V. Shanabrook, S. W. Huh, A. Y. Polyakov, M. Skowronski, J. J. Sumakeris, and M. J. O'Loughlin, Appl. Phys. Lett. 88, 052110 (2006).

${ }^{4}$ K. Danno, D. Nakamura, and T. Kimoto, Appl. Phys. Lett. 90, 202109 (2007).

${ }^{5}$ L. Storasta and H. Tsuchida, Appl. Phys. Lett. 90, 062116 (2007).

${ }^{6}$ L. Storasta, H. Tsuchida, T. Miyazawa, and T. Ohshima, J. Appl. Phys. 103, 013705 (2008).

${ }^{7}$ T. Hiyoshi and T. Kimoto, Appl. Phys. Express 2, 041101 (2009).

${ }^{8}$ K. Kawahara, J. Suda, and T. Kimoto, J. Appl. Phys. 111, 053710 (2012).

${ }^{9}$ L. Storasta, J. P. Bergman, E. Janzén, A. Henry, and J. Lu, J. Appl. Phys. 96, 4909 (2004).

${ }^{10}$ T. Hornos, A. Gali, and B. G. Svensson, Mater. Sci. Forum 679-680, 261 (2011).

${ }^{11}$ T. Kimoto, S. Nakazawa, K. Hashimoto, and H. Matsunami, Appl. Phys. Lett. 79, 2761 (2001).

${ }^{12}$ K. Danno and T. Kimoto, J. Appl. Phys. 100, 113728 (2006).

${ }^{13}$ N. T. Son, X. T. Trinh, L. S. Løvlie, B. G. Svensson, K. Kawahara, J. Suda, T. Kimoto, T. Umeda, J. Isoya, T. Makino, T. Ohshima, and E. Janzén, Phys. Rev. Lett. 109, 187603 (2012).

${ }^{14}$ K. Kawahara, X. Trinh, N. Son, E. Janzén, J. Suda, and T. Kimoto, "Investigation on origin of $\mathrm{Z}_{1 / 2}$ center in SiC by DLTS and EPR, 'Tu53'," in The 9th European Conference on Silicon Carbide and Related Materials, Saint-Petersburg, Russia, 2012.

${ }^{15}$ T. Miyazawa, M. Ito, and H. Tsuchida, Appl. Phys. Lett. 97, 202106 (2010).

${ }^{16}$ S. Ichikawa, K. Kawahara, J. Suda, and T. Kimoto, Appl. Phys. Express 5, 101301 (2012).

${ }^{17}$ T. Troffer, M. Schadt, T. Frank, H. Itoh, G. Pensl, J. Heindl, H. P. Strunk, and M. Maier, Phys. Status Solidi A 162, 277 (1997).

${ }^{18}$ S. G. Sridhara, L. L. Clemen, R. P. Devaty, W. J. Choyke, D. J. Larkin, H. S. Kong, T. Troffer, and G. Pensl, J. Appl. Phys. 83, 7909 (1998).

${ }^{19}$ M. Ikeda, H. Matsunami, and T. Tanaka, Phys. Rev. B 22, 2842 (1980).

${ }^{20}$ K. Danno and T. Kimoto, J. Appl. Phys. 101, 103704 (2007).

${ }^{21}$ A. Duijn-Arnold, T. Ikoma, O. G. Poluektov, P. G. Baranov, E. N. Mokhov, and J. Schmidt, Phys. Rev. B 57, 1607 (1998).

${ }^{22}$ P. Baranov, I. Il'in, and E. Mokhov, Phys. Solid State 40, 31 (1998). 
${ }^{23}$ K. Kawahara, M. Krieger, J. Suda, and T. Kimoto, J. Appl. Phys. 108, 023706 (2010).

${ }^{24}$ M. Bockstedte, A. Mattausch, and O. Pankratov, Phys. Rev. B 69, 235202 (2004).

${ }^{25}$ A. Mattausch, M. Bockstedte, and O. Pankratov, Phys. Rev. B 70, 235211 (2004).

${ }^{26}$ A. Gali, N. T. Son, and E. Janzén, Phys. Rev. B 73, 033204 (2006).

${ }^{27}$ X. Shen, M. P. Oxley, Y. Puzyrev, B. R. Tuttle, G. Duscher, and S. T. Pantelides, J. Appl. Phys. 108, 123705 (2010).

${ }^{28}$ F. Devynck, A. Alkauskas, P. Broqvist, and A. Pasquarello, AIP Conf. Proc. 1199, 108 (2009).

${ }^{29}$ T. Hiyoshi and T. Kimoto, Appl. Phys. Express 2, 091101 (2009).

${ }^{30}$ K. Kawahara, J. Suda, G. Pensl, and T. Kimoto, J. Appl. Phys. 108, 033706 (2010).

${ }^{31}$ G. A. Evans, J. W. Steeds, L. Ley, M. Hundhausen, N. Schulze, and G. Pensl, Phys. Rev. B 66, 352041 (2002).
${ }^{32}$ A. Mattausch, M. Bockstedte, O. Pankratov, J. W. Steeds, S. Furkert, J. M. Hayes, W. Sullivan, and N. G. Wright, Phys. Rev. B 73, 161201 (2006).

${ }^{33}$ J. W. Steeds and W. Sullivan, Phys. Rev. B 77, 195204 (2008).

${ }^{34}$ J. W. Steeds, W. Sullivan, S. A. Furkert, G. A. Evans, and P. J. Wellmann, Phys. Rev. B 77, 195203 (2008).

${ }^{35}$ F. Yan, R. P. Devaty, W. J. Choyke, A. Gali, T. Kimoto, T. Ohshima, and G. Pensl, Appl. Phys. Lett. 100, 132107 (2012).

${ }^{36}$ I. G. Ivanov, A. Gällström, R. Coble, R. Devaty, W. Choyke, and E. Janzén, Mater. Sci. Forum 717-720, 259 (2012).

${ }^{37}$ A. Gali, P. Deák, P. Ordejón, N. T. Son, E. Janzén, and W. J. Choyke, Phys. Rev. B 68, 125201 (2003).

${ }^{38}$ J. F. Ziegler, M. D. Ziegler, and J. P. Biersack, Nucl. Instrum. Methods Phys. Res. B 268, 1818 (2010).

${ }^{39}$ R. Devanathan and W. Weber, J. Nucl. Mater. 278, 258 (2000).

${ }^{40}$ J. D. Hong and R. F. Davis, J. Am. Ceram. Soc. 63, 546 (1980).

${ }^{41}$ J. D. Hong, R. F. Davis, and D. E. Newbury, J. Mater. Sci. 16, 2485 (1981). 